\title{
Strategies Analysis on the Tutorial System's Implementation in Vocational Colleges under the New Normal
}

\author{
Yunshan Liu \\ School of Education, Wuxi Institute of Commerce, Wuxi, Jiangsu Province, China
}

Keywords: New Normal, Vocational Colleges, Tutorial System, Strategy, Countermeasures.

\begin{abstract}
Under the new normal condition, it is a useful exploration to carry out the training mode of the Tutorial System in the vocational colleges, in order to solve problems, such as ubiquitous objectives of professional training, disconnection between teaching conditions and social needs, lack of teaching equipment, difficulties in students' role changing and so on. Only under the condition of mentor's appointment, clear responsibilities, smooth exchange between teachers and students sound assessment and evaluation, the implementation of Tutorial System's training model can promote its healthy development, enhance the overall quality of students, and then develop skilled application talents for society.
\end{abstract}

\section{Introduction}

Under the new normal, the state has invested a lot of manpower and material resources in vocational education, and links the vocational education with the future development of the country. The "State Council's decision on accelerating the development of modern vocational education" has carried out a master plan for China's vocational education system layout. Under the new normal, the development of vocational education is a strategic choice made by the Chinese government according to the new adjustment of domestic industrial structure, supply-side reform, "Internet $+"$ and so on. It is also a major measure taken according to the spirit of "Made in China 2025". For vocational institutions, it's a big challenge to cultivate the high-skilled personnel adapt to economic and social needs, to meet national development. In face of the new situation and new requirements, vocational education must carry out the reform of teaching methods, means, methods and training mode of personnel, implementation the Tutorial System training model in vocational college should be a natural result of reform.

\section{The Connotation and Characteristics of Tutorial System}

Mentor, refers to the teachers, who give specific guidance to students in cultural knowledge learning, research papers writing, experimental practice and others. The Tutorial System is an educational system, an innovative new model of education and teaching, which is characterized by close relationship between teachers and students. In which, teachers educated and teach students in thinking, learning, psychological and other aspects based on individual differences. In the development process of education and teaching, the Tutorial System is first used in undergraduate education and graduate education, for vocational education, due to differences in the objectives and positioning of personnel training, teaching methods means are essentially different to undergraduate education, but the Tutorial System is also applicable to higher vocational education. Practice shows that after the implementation of Tutorial System in vocational education, construction of curriculum, major and disciplinary has achieved remarkable results, and the students' practical ability and knowledge application ability have also been improved remarkably. The main practice and characteristics of Tutorial System in vocational colleges are that equipping at least two instructors to 
each student during the whole academic study, one is school mentor and the other is an instructor [1]. In the implementation of the Tutorial System, different vocational institution has different approach, and some school instructors are class teacher or counselor, whose working focus is education on students' daily life, behavior habits, mental health and other aspects, while some other school tutors are experienced full-time teachers, whose working focus are entrepreneurship and employment education, besides life education. These two different school tutors have their own characteristics, and in the specific implementation, schools should combine with their own situation to choose. Experienced technical staff is chosen as business mentor based on students' majors, whose working focus is education of students' professional knowledge, especially practical knowledge, professional ethics, vocational skills and other aspects. In the whole teaching process, the school mentor and business mentor have to work together to complete the education and teaching tasks from beginning to end. In addition, mentors also need deeper cooperation in the teaching materials construction, curriculum development, personnel training programs, research development and other aspects.

\section{The SWOT Analysis of Implementing Tutorial System in Vocational Colleges}

With the introduction, promotion and implementation of the Tutorial System in vocational colleges, good results have been achieved in the development of vocational education, and its significance and influence are more and more obvious. In order to further develop the positive role of Tutorial System and overcome the negative effects, the author simply analyzes the advantages, disadvantages and development prospects to implement Tutorial System in vocational education.

First, the implementation of Tutorial System changed disconnection between professional training objectives and production practice. In recent years, China's vocational education has been advocating more practice instead of theory, through compressing theoretical teaching time while increasing practice teaching time greatly. However, for various reasons, the implementation result is not satisfactory. After working, students are often unable to solve actual technical problems, and the reason is the serious disconnection between school learned knowledge and production practice-the learned knowledge and ability can't meet the job requirements. This is contrary to the personnel training goal of vocational education, which not only affects the quality of personnel training, but also affects the survival and development of vocational colleges. The implementation of Tutorial System training mode in vocational and educational institutions can make full use of the resources in and out of school, and school tutor and business mentor can learn from each other to achieve complementary advantages, and apply real project as a teaching content in the education and teaching process. Mentors apply theoretical knowledge, and practical skills throughout the teaching and teaching to meet the actual needs of business positions, so that students can graduate smoothly, adapt to the job fully, changing present disconnection situation between professional training objectives and production practice.

Second, the implementation of Tutorial System solves the status disconnection between present teaching situation and actual industry demand. At present, the domestic industry is carrying out industrial restructuring and supply side reform, following the German's proposition of "Industrial 4.0 high-tech strategic plan", China put forward "China made 2025". With growing domestic and foreign technology development, new technology, new materials, new ideas emerge in endlessly, and this new age has new requirements to teachers. However, teachers in Vocational Colleges have a lot of teaching and research work, besides daily practice of teaching and educating work, which are clearly conflict with the desire that teachers want to improve their practical skills to grasp the most cutting-edge technology timely. Therefore, teaching content cannot keep up with the industry development, the soft and hard environment of teaching disjointed with business needs seriously phenomenon, which would affect student's employment rate certainly. With implementation of Tutorial System , apply business mentor's understanding of industry's latest knowledge and skills to the training of students, it can not only improve the students' practical skills, so that students keep pace with industry , but also enhance the education and teaching level of teachers, so that education status can keep pace with industry and business needs. 
Third, the implementation of the Tutorial System can help vocational institutions step out of practical teaching equipment shortage. The personnel training goal of vocational education determines the importance of the cultivation of students' practical ability. The experiments and training equipment are the basic guarantee and conditions for the cultivation of skilled talents. However, due to limited investment funds, funding is difficult to place, most vocational institutions are in prevalence of practical teaching equipment [2], which will inevitably affect the students' learning effect of experiment and training course, including the improvement of student skills. The co-implementation of the Tutorial System with enterprises can make full use of existing equipment, equipment to carry out practical teaching, which will greatly ease the lack of professional teaching equipment in vocational colleges. Business mentor can bring students to the production line to feel the real working environment, to operate these devices while experiencing the professional atmosphere, while school are borrowing these equipment at the same time. The implementation of the Tutorial System can really open up the students' vision, enrich students' practical ability, and help vocational colleges ease shortage of teaching equipment in a certain extent,

Fourth, the implementation of the Tutorial System can help students complete the change of roles. Due to lack of understanding of self and society, pragmatic and hard-working spirit, college students exist a sense of loss to future and majors presently. After graduating, they are confused of what kind of job they can do, and, has a sense of fear to society, which have a great relationship with students' learning progress, academic achievement and personal accomplishment in school. This sense of fear will inevitably make students confused about the roles' change, making individual socialization, professional transition difficult in the future, to a certain extent, it also affected the student career planning and career development. After implementation of Tutorial System, the business mentor will present the talent demand standards to the skills of present industry, production processes, professional ethics and other information to students, under the guidance of the instructor, students gradually adapt into the real employment environment through visits, experience, practice and training process. When students are familiar with the job, they will gradually develop professional ethics and professional behavior norms, then achieve a gentle change in student roles.

\section{The Countermeasure of Implementing Tutorial System in Vocational Colleges}

Vocational colleges have made great achievements after the implementation of the Tutorial System, the students' thinking, behavior, career planning and knowledge and skills have improved greatly, but there are shortage existing in the position of responsibility, the rights and obligations of students and mentors, and the provisions of the Tutorial System evaluation mechanism and other aspects. Therefore, targeted strategic measures must be adopted to normalize the effect of Tutorial System.

First, we must effectively strengthen the appointment of two mentors. "Ministry of Education on strengthening the vocational education personnel training work views" clear the vocational education classroom teaching must be applied mainly to promote students to knowledge into practical skills. In order to meet the "opinions" requirement, we should pay special attention to the appointment of the mentor in the implementation of the Tutorial System, based on the "double division" requirements. For school tutor, choose from the professional and double qualified teachers, who have a wealth of professional knowledge, excellent practical skills, rich teaching and educating experience and high enthusiasm for work; school mentors' appointment should start from young teachers, and have obligations in training teaching system to let young teachers actively participate in production and research work consciously, then improve professional practice, scientific research ability and education and teaching level through the production and research cooperation. For business mentors, hire from professional enterprise engineers, technicians, technical experts, who have a wealth of technical work experience, good professional ethics, strong organization and coordination capacity and preaching mission. Persons, who meet these requirements, can be appointed as a business mentor. At the same time, appropriate policies need to be made in pay, job evaluation, study abroad, training and other aspects to encourage teachers and business technicians to participate in the Tutorial System 
to take talent training work. Under the protection of system, so mentors can be affirmed by school and community with a sense of accomplishment [3].

Second, we must make clear the responsibilities division of mentors. School tutors and business mentors are different in roles, units and management methods in the teaching process, however, they need to work together to complete the teaching tasks of students skills and ideological life. Therefore, to clear the responsibility of mentor is extremely important. The mainly responsibility of school tutor is theoretical knowledge transfer and personality psychology construction. Firstly, psychological counseling. Through the exchange of students, listening and other ways, school tutors can help students to resolve psychological pressure, release depressed mood, and correct their wrong ideas of students timely to keep their psychology in a normal state. Secondly, ideological guidance. School tutors can understand the interests of students, expertise, ideological and other information be through regular or irregular conversation to implement individualized teaching and guide students' personalized training. Thirdly, knowledge transfer. Knowledge transfer is the fundamental responsibility of the school mentor, they impart professional knowledge to students through the classroom teaching, after-school counseling, etc. Business mentor is related to the success or failure of the Tutorial System. In the stage of student training, business mentors play the leading role, their professional level, teaching ability, skill experience and craftsmen's spirit will directly affect the students' practice quality and charisma shaping. First, business mentors enhance students' practical skills and ability to solve practical technical problems through on-site guidance and demonstration teaching; Second, business mentors develop students Moral, hard-working spirit and excellence of the work attitude with their own craftsmen spirit, product quality awareness and safety awareness; Third, business mentors allow students to be familiar with the business environment, culture, and chapter procedures through their words and deeds.

Third, we should ensure smooth communication between mentors and students. Due to impact of working nature, school mentor and business mentor are not same in training methods, but in the process of personnel training, they should communicate, coordinate with each other to adjust timely. According to their own circumstances, school tutors and business mentors can take different ways to guide students, that school tutor can use the working hours or spare time to have face to face communication with students, or by modern means, such as telephone, QQ, WeChat, microblog. The content would cover students' doubts encountered in the learning and training process, difficulties encountered in life, psychological problems and ideological fluctuations and other issues. All these problems that the students encountered would be processed timely, and mentors need guide students to study harder to learn solid, professional knowledge in school. Business mentors can come to the school or in the enterprise site to guide students, modern means can also been used, the exchange contents of students covers doubts in the learning process of practical operation, professional norms, job responsibilities. Business mentors should be a good consultant of student practice class, a good guider when students are on the road of employment.

Fourth, we should improve the evaluation mechanism of the mentor. Tutorial System of personnel training model as a new teaching model is still in the exploratory stage, for the implementation of the Tutorial System of personnel training mode of professional, should be their own departments to conduct regular assessment and evaluation. Evaluation of the process evaluation and the results of the evaluation combined [4], process evaluation is to assess the implementation of the Tutorial System of the process, teaching methods, curriculum and other content, the results of the evaluation of the Tutorial System after the implementation of the teaching effect, teaching quality, teaching objectives Implementation and so on. The ultimate goal of the evaluation is to fully evaluate the effectiveness of the Tutorial System, the existing problems and the direction of improvement. In the mentor evaluation assessment, the two instructors in the guidance of students to make a fair self-evaluation, the school mentor and business mentor according to the other side of the usual work and the actual situation of students, to evaluate each other, and this At the same time, schools and students have to participate in the evaluation, the school combined with the two instructors of the daily work of the students to cultivate the effect of the two tutors of professional level, teaching ability and other content evaluation results, each student with their daily guidance Situation, the evaluation of the work 
of the two mentors. We should give re-appointment and rewards to the qualified instructors and dismiss the unqualified ones.

\section{References}

[1] Chi Ma. Higher vocational colleges "multi Tutorial System" education model research [J]. Modern vocational education, 2016 (16).

[2] Yan Wu, Na Li. Vocational college Tutorial System teaching practice and exploration [J]. Technology horizon, 2016 (27).

[3] Hai-mei Wang. On the implementation of vocational education Tutorial System [J]. Vocational Technology, 2016 (14).

[4] Shan Ye. Establishment of the Mode of Professional Tutorial System [J]. Industry and Technology Forum, 2017, (16). 